\title{
Cystofilobasidium lacus-mascardii sp. nov., a basidiomycetous yeast species isolated from aquatic environments of the Patagonian Andes, and Cystofilobasidium macerans sp. nov., the sexual stage of Cryptococcus macerans
}

\author{
Diego Libkind, ${ }^{1}$ Mário Gadanho, ${ }^{2}$ Maria van Broock ${ }^{1}$ \\ and José Paulo Sampaio
}

Correspondence José Paulo Sampaio jss@fct.unl.pt

\author{
${ }^{1}$ Laboratorio de Microbiología Aplicada y Biotecnología, Universidad Nacional del Comahue, Centro \\ Regional Universitario Bariloche (CRUB), CONICET (Consejo Nacional de Investigaciones \\ Científicas y Tecnológicas), Bariloche, Río Negro, Argentina \\ ${ }^{2}$ Centro de Recursos Microbiológicos, Departamento de Ciências da Vida, Faculdade de Ciências e \\ Tecnologia, Universidade Nova de Lisboa, 2829-516 Caparica, Portugal
}

\begin{abstract}
Here, we report on two novel sexual basidiomycetous red yeast species of the genus Cystofilobasidium. Cystofilobasidium lacus-mascardii sp. nov. is based on sexually compatible strains isolated from Lake Mascardi, an ultraoligotrophic lake in north-western Patagonia, Argentina. Following the discovery of the first isolate of this species, additional (sexually compatible) strains were isolated using a selective medium containing erythritol as the sole source of carbon. The second novel species corresponds to the sexual state of Cryptococcus macerans. In spite of accounts over the last 20 years of sexually compatible strains of this species, the complete life has never been observed. We provide evidence of a Cystofilobasidium-like basidial stage with teliospores and slender holobasidia, based on the study of self-fertile (homothallic) and self-sterile (heterothallic) isolates of Cryptococcus macerans. A revised molecular phylogeny of the genus Cystofilobasidium is presented and the most salient features of Cystofilobasidium lacus-mascardii sp. nov. (type strain CBS $10642^{\top}=$ PYCC $5819^{\top}=$ CRUB $1046^{\top}$ ) and Cystofilobasidium macerans sp. nov. (type strain CBS $10757^{\top}$ ) are discussed and compared with those of the remaining species in the genus. Information on additional Patagonian isolates belonging to the Cystofilobasidiales is also included in this report.
\end{abstract}

The yeasts of the genus Cystofilobasidium are classified in the order Cystofilobasidiales (Fell et al., 1999). The most distinctive phenotypic features of the four species presently classified in Cystofilobasidium are the formation of teliospores that give rise to a non-septate basidium, the production of visible carotenoid pigments, the formation of starch-like compounds, the ability to utilize D-glucuronate and inositol as sole carbon sources and the assimilation of nitrate as sole nitrogen source. Whereas Cystofilobasidium capitatum is homothallic, Cystofilobasidium bisporidii, Cystofilobasidium infirmomi-

Abbreviations: ITS, internal transcribed spacer; LSU, large subunit; MP, maximum parsimony.

The GenBank/EMBL/DDBJ accession number numbers for the sequences determined in this study are EF613496-EF613498 and EU082223-EU082228 (LSU rDNA D1D2 domain) and EF613495 and EU082229-EU082233 (compete ITS region and 5.8S rDNA). niatum and Cystofilobasidium ferigula have a heterothallic life cycle.

In a survey of the yeast community of low- to non-polluted oligotrophic lakes of north-western Andean Patagonia, 64 isolates representing six genera and 15 species were found and characterized by molecular techniques (Libkind et al., 2003). As a result of this study, two novel ballistoconidiaproducing yeast species, Sporidiobolus longiusculus and Sporobolomyces patagonicus, were described (Libkind et al., 2005). Among the pink-coloured Patagonian isolates, some members of the Cystofilobasidiales were found, namely strains of Cystofilobasidium capitatum and Cystofilobasidium infirmominiatum and strain CRUB 1046, the first isolate of a novel species described in this report as Cystofilobasidium lacus-mascardii sp. nov.

A second study concerned the investigation of the sexual stage of Cryptococcus macerans, a pink-coloured basidiomycetous yeast species that also belongs to the order 
Cystofilobasidiales. Sexual compatibility between strains of this species was first reported by Rodrigues de Miranda (1984). An earlier brief remark was made on sexual traits of Cryptococcus macerans by Ahearn \& Roth (1966), but it concerned solely the occurrence of homothallic strains that seemed to produce teliospores. In his comment, Rodrigues de Miranda (1984) mentioned that mating types were found, but the complete life cycle was not observed. It is therefore not clear whether Rodrigues de Miranda observed only true mycelium in the crosses or whether teliospores were also detected. In any case, it seems obvious that the basidial stage was not observed. As a consequence of these studies, CBS $2206^{\mathrm{T}}$ (the type strain of Cryptococcus macerans) and CBS 6532 were designated mating type A1 (originally mating type a) and strains CBS 2425 and CBS 2426 were designated mating type A2 (originally mating type $\alpha$ ). Mating studies in Cryptococcus macerans were repeated by Fell \& Statzell-Tallman (1998), but the results were negative and the species continued to be treated as asexual.

In 2000, we isolated a pink yeast strain (A006) from the estuary of the Tagus River (Portugal) that produced clamped mycelium and teliospores in the absence of mating. Molecular identification based on sequence analysis of the D1D2 region of the large-subunit (LSU) rDNA indicated that this isolate belonged to Cryptococcus macerans. Such findings prompted us to restudy the sexual cycle in this species. We used the strains employed by Rodrigues de Miranda (1984) and also other strains isolated from various sources. In parallel, we tried to induce teliospore germination in strain A006. These investigations allowed us to observe the entire sexual cycle of Cryptococcus macerans, which is described below. Such findings support the recognition of Cystofilobasidium macerans sp. nov.

The strains and sequences of Cystofilobasidium lacusmascardii and Cystofilobasidium macerans studied in this report are listed in Table 1, together with additional members of Cystofilobasidium isolated in Patagonia. Isolations in north-western Patagonia were done by filtering subsurface water samples as described by Libkind et al. (2003). The aquatic environments surveyed are oligotrophic to ultraoligotrophic temperate water bodies of glacial origin and have been classified as warm monomictic with a period of summer stratification (Díaz et al., 2000). Water samples were collected in December and January in 2001-2002 and in 2002-2003. Water temperatures at the time of collection ranged between 12 and $15{ }^{\circ} \mathrm{C}$. In a second phase of this study, the isolation of additional strains of Cystofilobasidium lacus-mascardii was carried out by filtration of water samples and culturing in YM agar $\left(1^{-1}\right.$ : yeast extract, $3 \mathrm{~g}$; malt extract, $3 \mathrm{~g}$; peptone, $5 \mathrm{~g}$; glucose, $10 \mathrm{~g}$; agar, $20 \mathrm{~g}$ ), $\mathrm{pH} 4$, containing $0.01 \%$ chloramphenicol and in YNB erythritol agar $\left(1^{-1}\right.$ : YNB, $6.7 \mathrm{~g}$; erythritol, $5 \mathrm{~g}$; agar, $15 \mathrm{~g}$ ), $\mathrm{pH} 5$, containing $0.02 \%$ chloramphenicol. For the latter culture medium, larger volumes of water were filtered (up to $2 \mathrm{l}$ ).
For determination of sexual compatibility, pairs of 2- to 4day-old cultures were crossed on cornmeal agar and incubated at low temperature $\left(16{ }^{\circ} \mathrm{C}\right)$ and at room temperature $\left(20-23{ }^{\circ} \mathrm{C}\right)$. The crosses were examined for production of mycelium and teliospores after 1,2 and 4 weeks. For microscopy, an Olympus BX50 microscope equipped with phase-contrast optics was used. The colour of the cultures was assessed using the mycological colour chart of Rayner (1970). Physiological characterization was done according to Yarrow (1998). Additional assimilation tests employing aldaric acids and aromatic compounds were performed as described by Fonseca (1992) and Sampaio (1999), respectively.

For PCR fingerprinting, the MSP-PCR technique was used employing the synthetic oligonucleotide $(\mathrm{GAC})_{5}$ as primer. The DNA extraction protocol, PCR and electrophoresis conditions and gel image-analysis procedures were those reported in Sampaio et al. (2001b). For DNA sequence analysis, DNA extraction, PCR amplification, purification and cycle sequencing, we followed the protocol of Sampaio et al. (2001b). DNA was amplified using primers ITS5 (5'-GGAAGTAAAAGTCGTAACAAGG) and LR6 (5'CGCCAGTTCTGCTTACC). Cycle sequencing of the 600-650 bp region at the $5^{\prime}$ end of the LSU rDNA D1/ D2 domain employed forward primer NL1 (5'GCATATCAATAAGCGGAGGAAAAG) and reverse primer NL4 (5'-GGTCCGTGTTTCAAGACGG). The internal transcribed spacer (ITS) region was sequenced using the forward primer ITS1 (5'-TCCGTAGGTGAACCTGCGG) and the reverse primer ITS4 (5'-TCCTCCGCTTATTGATATGC). Sequences were obtained with an Amersham Pharmacia ALF express II automated sequencer using standard protocols.

Multiple sequence alignments were obtained with MUSCLE (Edgar, 2004). Phylogenetic placement of the novel species was inferred using the maximum-parsimony (MP) method. Phylogenetic analyses were conducted in MEGA4 (Tamura et al., 2007). All positions containing gaps and missing data were eliminated from the dataset. There were a total of 549 positions in the final dataset, out of which 81 were parsimony informative. The bootstrap test (Felsenstein, 1985) was carried out on 1000 replicates and the corresponding consensus tree was taken to represent the evolutionary history of the taxa analysed. Branches corresponding to partitions reproduced in fewer than $50 \%$ of the bootstrap replicates were collapsed. The MP tree was obtained using the close-neighbour-interchange algorithm (Nei \& Kumar, 2000) with search level 3, in which the initial trees were obtained with the random addition of sequences (100 replicates).

\section{Patagonian survey and Cystofilobasidium lacus- mascardii sp. nov.}

During a survey of red yeast biodiversity in aquatic environments from Patagonia, Argentina, the pinkcoloured yeast strain CRUB 1046 was the only pigmented 
Table 1. Strains of Cystofilobasidium used in this study

MT, Mating type; SF, self-fertile; ASEX, asexual; ND, not determined/no data available.

\begin{tabular}{|c|c|c|c|c|}
\hline \multirow[t]{2}{*}{ Strain } & \multicolumn{2}{|c|}{ GenBank accession no. } & \multirow[t]{2}{*}{ Sexuality } & \multirow[t]{2}{*}{ Source } \\
\hline & D1/D2 & ITS & & \\
\hline \multicolumn{5}{|c|}{ Cystofilobasidium lacus-mascardii sp. nov. } \\
\hline CBS $10642^{T_{\star}}$ & AY158642 & EF613495 & MT A1 & Subsurface water from Lake Mascardi \\
\hline CBS $10643^{*}$ & EF613497 & ND & MT A2 & Subsurface water from Lake Mascardi \\
\hline CRUB $1175^{\star}$ & $\mathrm{ND}$ & $\mathrm{ND}$ & MT A2 & Subsurface water from Lake Mascardi \\
\hline \multicolumn{5}{|c|}{ Cystofilobasidium macerans sp. nov. } \\
\hline CBS 2206 & AF189848 & AF444329 & MT A1 & $\begin{array}{l}\text { Dew-retted flax straw, locality unknown (type strain of } \\
\text { Cryptococcus macerans) }\end{array}$ \\
\hline CBS 2425 & AF075477 & AF444317 & MT A2 & Dew-retted flax straw, Denmark \\
\hline CBS 2426 & EU082223 & EU082229 & MT A2 & Dew-retted flax, locality unknown \\
\hline CBS 6532 & EU082224 & EU082230 & MT A1 & $\begin{array}{l}\text { Mouth of newly born Axis axis (stag), Paris Zoological } \\
\text { Park, France }\end{array}$ \\
\hline CBS $10757^{\mathrm{T}}$ & EU082225 & EU082231 & SF & Estuarine water from Tagus River, Lisbon, Portugal \\
\hline CBS 6984 & AF444712 & AF444448 & SF & Leaf of cereal, locality unknown \\
\hline CBS 9032 & AF406924 & EU082232 & $\mathrm{ND}$ & Flower of Vicia villosa, Germany \\
\hline PYCC 4482 & EU082226 & EU082233 & ND & Flower of Cineraria sp., Portugal \\
\hline PYCC 4737 & ND & ND & $\mathrm{ND}$ & Grasshopper, Portugal \\
\hline PYCC 4792 & ND & $\mathrm{ND}$ & $\mathrm{ND}$ & Unknown \\
\hline A 056005 & EU082227 & $\mathrm{ND}$ & $\mathrm{ND}$ & Submerged leaf, River Olo, Portugal \\
\hline A 007006 & EU082228 & $\mathrm{ND}$ & $\mathrm{ND}$ & Submerged leaf, River Olo, Portugal \\
\hline CRUB $1174^{\star}$ & EF613497 & ND & ND & Water from Lake Mascardi \\
\hline CRUB $1178^{*}$ & DQ513290 & $\mathrm{ND}$ & $\mathrm{ND}$ & Manso glacial pond \\
\hline KCTC $17049 \dagger$ & AF459664 & $\mathrm{ND}$ & ND & Aquatic plant, Korea \\
\hline KCTC $17050 \dagger$ & AF459665 & $\mathrm{ND}$ & $\mathrm{ND}$ & Aquatic plant, Korea \\
\hline KCTC $17051 \dagger$ & AF459666 & $\mathrm{ND}$ & $\mathrm{ND}$ & Rhizosphere soil from Panax ginseng, Korea \\
\hline KCTC $17052 \dagger$ & AF459667 & $\mathrm{ND}$ & $\mathrm{ND}$ & Rhizosphere soil from Platycodon grandiflorum, Korea \\
\hline $\mathrm{S} 3 \mathrm{~A} \dagger$ & AY052482 & AY052490 & $\mathrm{ND}$ & Frozen environmental sample, Iceland \\
\hline MZKI K-530† & DQ538365 & ND & ND & Artic glacier, Svalbard, Norway \\
\hline VTT C-04538† & DQ377662 & ND & ND & Lager beer malt, Finland \\
\hline HB $980 \dagger$ & AJ507767 & $\mathrm{ND}$ & $\mathrm{ND}$ & Soil in seasonally flooded forest, Austria \\
\hline $1493 \dagger$ & ND & AM262438 & $\mathrm{ND}$ & Dactylis glomerata \\
\hline CRUB $1174^{*}$ & EF613497 & $\mathrm{ND}$ & $\mathrm{ND}$ & Subsurface water from Lake Mascardi \\
\hline CRUB $1178^{*}$ & DQ513290 & $\mathrm{ND}$ & $\mathrm{ND}$ & Meltwater from Manso glacial pond \\
\hline \multicolumn{5}{|c|}{ Cystofilobasidium infirmominiatum } \\
\hline CRUB $1045^{*}$ & AY158643 & $\mathrm{ND}$ & MT A1 & Subsurface water from Lake Fonck \\
\hline CRUB $1066^{*}$ & EF613496 & $\mathrm{ND}$ & ASEX & Subsurface water from Lake Gutierrez \\
\hline \multicolumn{5}{|c|}{ Cystofilobasidium capitatum } \\
\hline CRUB $1047^{\star}$ & AY849807 & $\mathrm{ND}$ & SF & Subsurface water from Lake Nahuel Huapi \\
\hline CRUB $1067^{\star}$ & $\mathrm{ND}$ & $\mathrm{ND}$ & SF & Subsurface water from Lake Gutierrez \\
\hline CRUB $1008^{*}$ & $\mathrm{ND}$ & $\mathrm{ND}$ & ASEX & Austrocedus chilensis, native woodland soil \\
\hline CRUB $1012^{*}$ & ND & $\mathrm{ND}$ & ASEX & Austrocedus chilensis, native woodland soil \\
\hline CRUB $1014^{*}$ & ND & $\mathrm{ND}$ & ASEX & Austrocedus chilensis, native woodland soil \\
\hline CRUB $1015^{*}$ & ND & $\mathrm{ND}$ & ASEX & Austrocedus chilensis, native woodland soil \\
\hline
\end{tabular}

*Strains isolated from Nahuel Huapi National Park, Patagonia, Argentina.

$\dagger$ Only the DNA sequence(s) was studied.

isolate recovered from the ultraoligotrophic Lake Mascardi. This strain was initially identified as Cryptococcus macerans based on the assimilation of inositol, D-glucuronate and erythritol as sole carbon sources, assimilation of nitrate as the sole nitrogen source and the production of starch-like compounds (Barnett et al., 2000). The ability to assimilate erythritol was considered the key criterion for phenotypic identification as Cryptococcus macerans, as reported by Sampaio et al. (2001a). However, since CRUB 1046 and representative strains of Cryptococcus macerans gave different banding patterns in studies employing the MSPPCR molecular fingerprinting approach (Fig. 1), the initial 


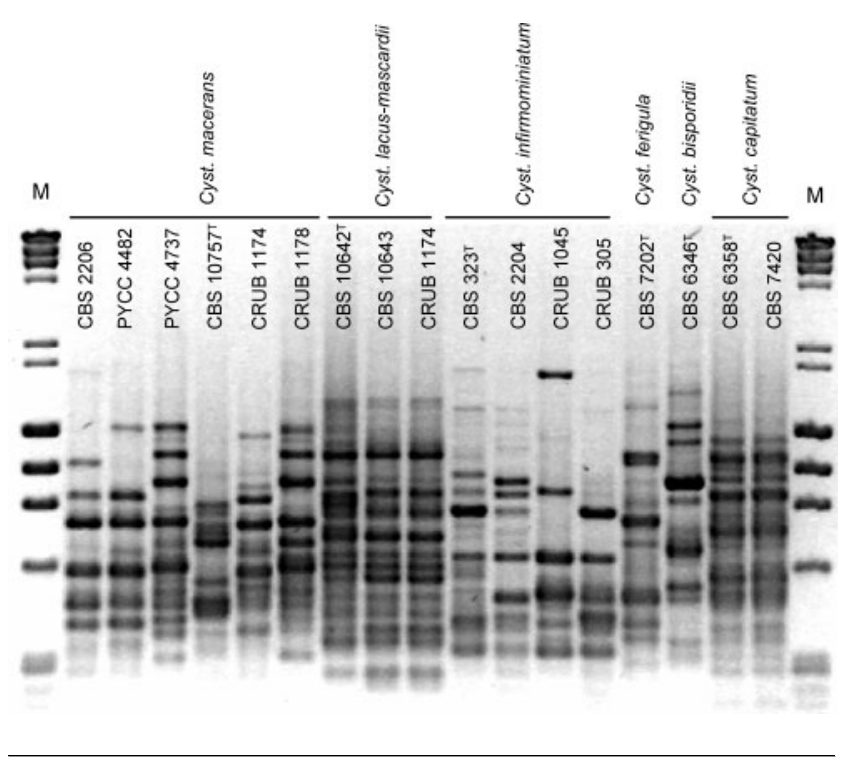

Fig. 1. Microsatellite-primed PCR fingerprints of strains of Cystofilobasidium lacus-mascardii $\mathrm{sp}$. nov. and related taxa obtained with primer $(\mathrm{GTG})_{5}$. Lanes $\mathrm{M}$, phage $\lambda$ DNA cleaved with HindIII/ $\phi$ X174 DNA cleaved with Haelll.

identification of CRUB 1046 was questioned. Furthermore, CRUB 1046 showed MSP-PCR profiles distinct from those of the other known Cystofilobasidium species (Fig. 1).

Since we were interested in obtaining additional isolates of this putative novel species, we devised a selective isolation approach employing erythritol as the sole carbon source in the isolation medium. This strategy allowed us to isolate 10 pink-coloured yeast strains from the water of Lake Mascardi. Three strains (CRUB 1172, CRUB 1174 and CRUB 1175) had the ability to form starch-like compounds and thus were analysed. Interestingly, while CRUB 1174 displayed DNA fingerprints resembling those of
Cryptococcus (Cystofilobasidium) macerans, CRUB 1172 and CRUB 1175 had MSP-PCR profiles similar to that of CRUB 1046 (Fig. 1). Mating experiments using CRUB 1046, CRUB 1172 and CRUB 1175 in pairwise combinations resulted in the formation of true mycelium with clamp connections and teliospores (Fig. 2b), which provided additional evidence that these strains were conspecific. It was observed that CRUB 1046 was sexually compatible with CRUB 1172 and CRUB 1175. Germination of teliospores was obtained by transferring agar blocks with 2-month-old teliospores grown on cornmeal agar (Difco) to $2 \%$ water agar. A slender, cylindrical holobasidium was produced with terminal basidiospores (Fig. 2c). Basidiospores of Cystofilobasidium lacus-mascardii were larger than those of Cystofilobasidium infirmominiatum and Cystofilobasidium macerans (described in this report, see below), two species with similar basidial morphology.

Phylogenetic analysis of the LSU rDNA D1/D2 domain and complete ITS sequences confirmed that strains CRUB 1046, CRUB 1172 and CRUB 1175 represent a novel yeast species within the Cystofilobasidiales (Fig. 3), for which the name Cystofilobasidium lacus-mascardii sp. nov. is proposed.

\section{Sexual stage of Cryptococcus macerans}

We crossed the four strains studied by Rodrigues de Miranda (1984) on cornmeal agar and incubated the plates at low temperature $\left(16{ }^{\circ} \mathrm{C}\right)$ and at room temperature $(20-$ $23{ }^{\circ} \mathrm{C}$ ). These assays were repeated at least six times on different occasions. Negative results were obtained for most of the experiments, as neither true mycelium nor teliospores were formed. On a single occasion, positive results (formation of mycelium without clamp connections and teliospores) were obtained for the cross of CBS $2206 \times$ CBS 2426 incubated at $16^{\circ} \mathrm{C}$. We also crossed other

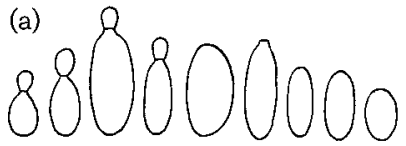

(b)

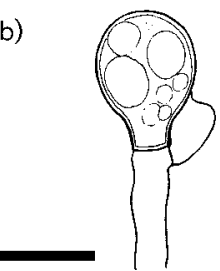

(c)

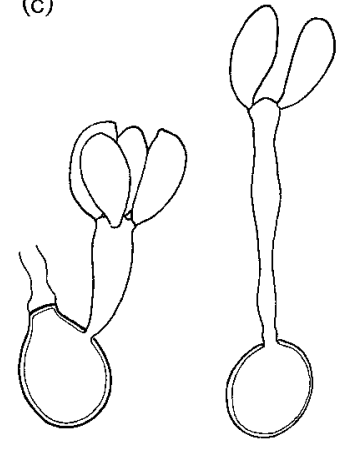

(d)

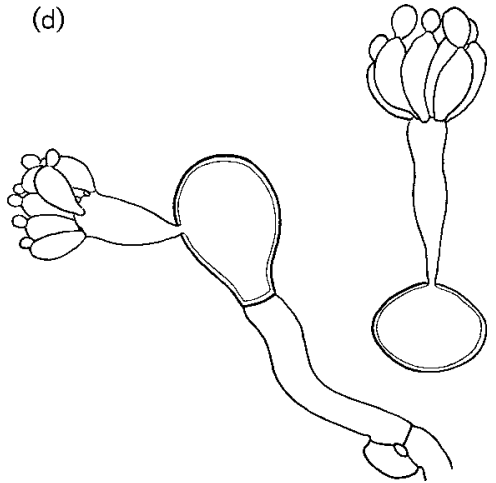

Fig. 2. Line drawings of Cystofilobasidium lacus-mascardii sp. nov. (a) Yeast cells of CBS $10642^{\top}$ on MYP agar after 6 days at $20{ }^{\circ} \mathrm{C}$. (b) Terminal teliospore of CBS $10642 \times$ CBS 10643 . Note the clamp connection at the base of the teliospore. (c, d) Germinated teliospores with basidia and basidiospores of CBS $10642 \times$ CBS 10643 . Note that, in (d), the basidiospores are forming buds while still attached to the basidia. Bar, $10 \mu \mathrm{m}$ (same for all panels). 


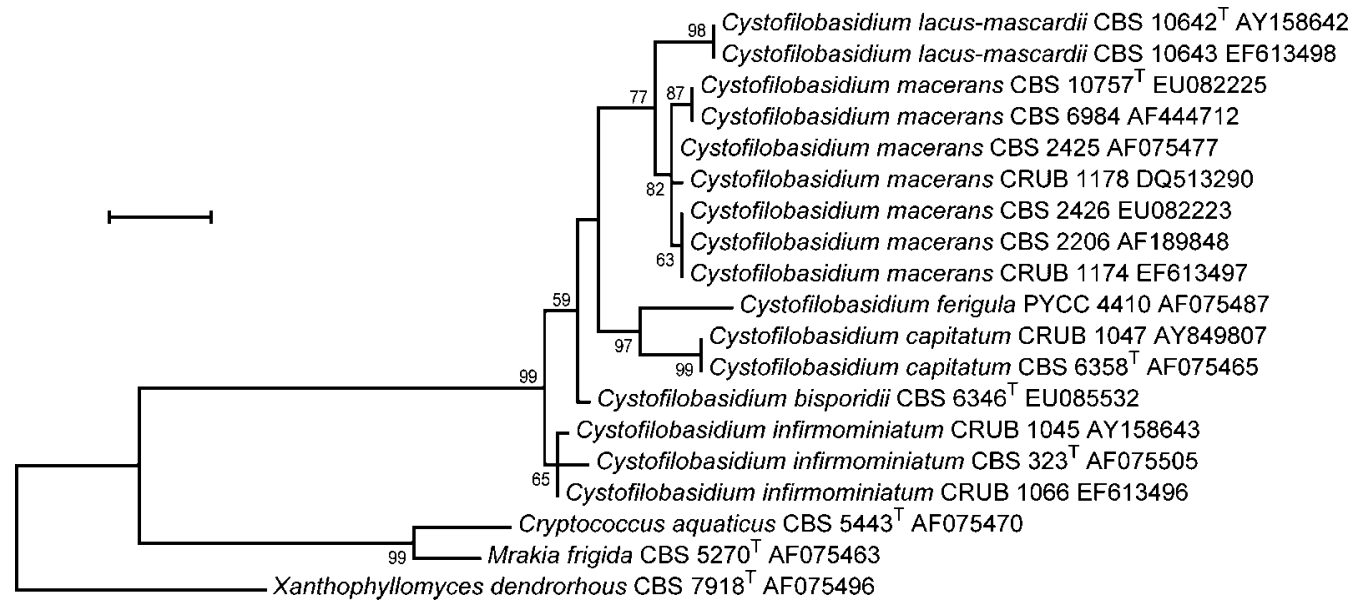

Fig. 3. Phylogenetic placement of strains of Cystofilobasidium lacus-mascardii sp. nov. and Cystofilobasidium macerans sp. nov. within the genus Cystofilobasidium, inferred using the MP method and based on partial LSU rDNA sequences (D1/D2 domains). Consensus tree of 261 most-parsimonious trees rooted with Xanthophyllomyces dendrorhous CBS $7918^{\top}$. Branch lengths reflect the number of changes over the whole sequence. Bar, 10 changes. Numbers on branches are percentage bootstrap values (1000 replicates; values below $50 \%$ are not shown). GenBank accession numbers are indicated after strain names.

cultures that had been isolated more recently and identified as Cryptococcus macerans by molecular methods. These cultures were mated among themselves and with the four strains mentioned above, but the sexual stage was never obtained. With respect to self-fertile isolates, we studied two strains: CBS 10757 (=A006), isolated by us from estuarine water, and CBS 6984, isolated in 1977 from a leaf of a cereal by J. A. von Arx and originally deposited at CBS as Rhodosporidium sp. Using sequence analysis of the D1/ D2 region, Scorzetti et al. (2002) had identified this isolate as Cryptococcus macerans. Both strains produced true mycelium abundantly but without clamp connections. Teliospores were formed in large amounts and had similar morphologies in the two strains. Teliospores from these two strains, and also those from the cross of CBS $2206 \times$ CBS 2426 , were subjected to a resting period of 35 months in demineralized water at $4{ }^{\circ} \mathrm{C}$. Agar cubes containing the teliospores were then transferred to $2 \%$ water agar and incubated at $18{ }^{\circ} \mathrm{C}$. Germination was observed after $48 \mathrm{~h}$ for the heterothallic and self-fertile strains. Upon germination, the teliospores gave rise to slender, non-septate basidia that could reach $40 \mu \mathrm{m}$ in length (Fig. 4) and had an apical swelling where relatively large basidiospores were formed. Basidiospores germinated by budding, and this process frequently occurred while the basidiospores were still attached to the basidium (Fig. 4).

In order to analyse possible sequence polymorphisms within Cystofilobasidium macerans sp. nov., we investigated 20 LSU rDNA D1/D2 sequences and 10 complete ITS sequences (see Table 1). Interestingly, the two self-fertile strains and the sequence of strain S3A (Birgisson et al., 2003) had two nucleotide substitutions in the D1/D2 region when compared with the heterothallic strains and all the remaining strains or sequences investigated by us. In the comparison of ITS sequences, five substitutions and one insertion separated these three strains from the others. It would be interesting to determine whether isolate $\mathrm{S} 3 \mathrm{~A}$ is also self-fertile, but unfortunately this strain was not available for study. A few other sequence polymorphisms were detected in both the D1/D2 and ITS sequences, but we were unable to correlate them with sexuality, geographical origin or type of substrate of isolation.

\section{Latin diagnosis of Cystofilobasidium lacus- mascardii Libkind, van Broock et Sampaio sp. nov.}

Fungus dimorphus Agaricomycotinorum, Cystofilobasidialium. In statu unicellulari cellulae ovoideae ad cylindraceae, 2-4×4$7 \mu \mathrm{m}$. Mycelium 3-4 $\mu \mathrm{m}$ diametro, conjugatione culturarum compatibilium procreatur, fibulatum. Teliosporae subglobosae, 8-10 × 10-14 $\mu \mathrm{m}$. Basidia $2-4 \times 10-25 \mu \mathrm{m}$, basidiosporae ovoideae $(4-5 \times 7-10 \mu \mathrm{m})$. Characteres biochemici physiologicique in Tabula 2 describuntur. Sequentiae acidi nucleici ITS et partium D1/D2 submonadis majoris ribosomalis typi in collectione sequentiarum acidi nucleici NCBI (http:// www.ncbi.nlm.nih.gov) numeris EF613495 et AY158642 depositae sunt. Positio phylogenetica in Fig. 3 illustratur. Cultura typica CBS $10642^{\mathrm{T}}$ in Centraalbureau voor Schimmelcultures (CBS), Ultrajecti, Hollandia, conservatur.

\section{Description of Cystofilobasidium lacus-mascardii Libkind, van Broock et Sampaio sp. nov.}

Cystofilobasidium lacus-mascardii (la'cus-mas.car' di.i. N.L. gen. n. lacus-mascardii of Lake Mascardi, Andean 
(a)

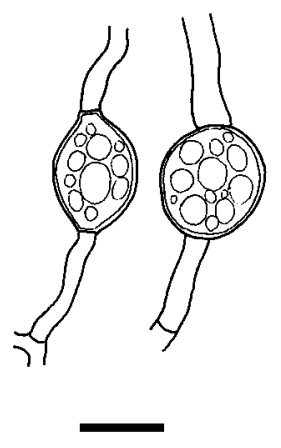

(b)

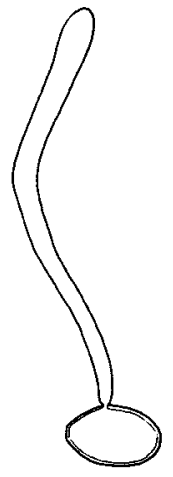

(c)

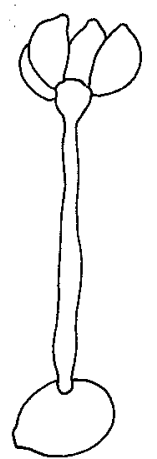

(d)

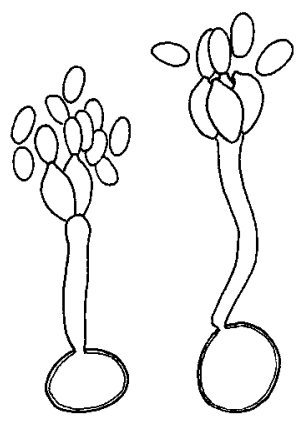

0000

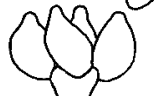

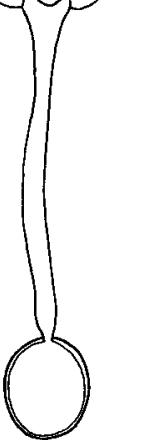

Fig. 4. Line drawings of Cystofilobasidium macerans sp. nov. CBS $10757^{\top}$, CBS 6984 and CBS 2206×CBS 2426. (a) Hyphae and mature teliospores (note the absence of clamp connections). (b) Initial stage of teliospore germination with young basidium. (c) Basidium with four basidiospores. (d) Mature basidia with basidiospores that are forming yeast cells by budding while still attached to the basidia. Bar, $10 \mu \mathrm{m}$ (same for all panels).

Patagonia, Argentina, from where the first strains were isolated).

Dimorphic. Belongs to the subphylum Agaricotinomycotina, class Tremellomycetes, order Cystofilobasidiales. Yeast cells after 2 days on MYP agar (malt extract, $0.7 \%$, w/v; yeast extract, $0.05 \% \mathrm{w} / \mathrm{v}$; soytone peptone, $0.25 \% \mathrm{w} / \mathrm{v}$; agar, $1.5 \%$ w/v) are ovoid to cylindrical, $2-4 \times 4-7 \mu \mathrm{m}$ (Fig. 2a). After 1 month at $20-23{ }^{\circ} \mathrm{C}$, the streak culture is peach to saffron coloured (Rayner, 1970), the surface is glistening and smooth, texture is butyrous and the margin is entire. Unable to ferment glucose. Heterothallic, and two mating types are known. The sexual stage develops on cornmeal agar and involves the formation of clamped hyphae that are relatively wide $(3-4 \mu \mathrm{m}$ in diameter) and give rise to subglobose teliospores $(8-10 \times 10-14 \mu \mathrm{m})$. Two-month-old teliospores germinate after transfer to $2 \%$ water agar. The basidium is slender and non-septate $(2-4 \times 10-25 \mu \mathrm{m})$. Basidiospores form terminally and are sessile, subglobose to ovoidal $(4-5 \times 7-10 \mu \mathrm{m})$. Basidiospores germinate by budding, and buds can be observed when the basidiospores are still attached to the basidium. Physiological and biochemical properties are depicted in Table 2, salient physiological features are shown in Table 3 and the phylogenetic placement of the species is presented in Fig. 3.

Strains have been deposited at the Centraalbureau voor Schimmelcultures (CBS), Utrecht, The Netherlands, at the Portuguese Yeast Culture Collection (PYCC), Caparica, Portugal, and at Centro Regional Universitario Bariloche (CRUB), Bariloche, Argentina. Strain CBS $10642^{\mathrm{T}}$ $\left(=\right.$ PYCC $5819^{\mathrm{T}}=$ CRUB $\left.1046^{\mathrm{T}}\right)$ is the type strain and mating type Al and strains CBS 10643 (=PYCC 5820 $=$ CRUB 1172) and CRUB 1175 are assigned to mating type A2. All strains were isolated from subsurface water by one of us (D. L.) at the Tronador's arm of Lake Mascardi (41

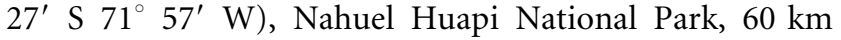
south-east of the city of San Carlos de Bariloche, Rio Negro Province, Patagonia, Argentina.

\section{Latin diagnosis of Cystofilobasidium macerans Sampaio sp. nov.}

Fungus dimorphus Cystofilobasidialium (Tremellomycetes, Agaricomycotina). Hyphae 3-3.5 $\mu \mathrm{m}$ diametro, hyalinae, efibulatae. Teliosporae aurantio-brunneae, globosae (9$12 \mu \mathrm{m})$ ad subglobosae $(8-10 \times 12-14 \mu \mathrm{m})$. Basidia aseptata, 2-3 $\times 20-40 \mu \mathrm{m}$. Basidiosporae sessiles, ovoideae ad guttiformes, 3-4 $\times 6-7 \mu \mathrm{m}$, gemmis germinant. Cultura typica CBS $10757^{\mathrm{T}}$ in Centraalbureau voor Schimmelcultures (CBS), Ultrajecti, Hollandia, conservatur.

\section{Description of Cystofilobasidium macerans Sampaio sp. nov.}

Anamorphic stage: Cryptococcus macerans (Frederiksen) Phaff \& Fell.

Hyphae hyaline (3-3.5 $\mu \mathrm{m}$ in diameter), without clamp connections. Teliospores lateral, terminal or intercalary on the mycelium. Mature teliospores are orange-browncoloured, globose $(9-12 \mu \mathrm{m})$ to subglobose $(8-10 \times 12-$ $14 \mu \mathrm{m})$. Upon germination, teliospores form slender, nonseptate basidia, $2-3 \times 20-40 \mu \mathrm{m}$. Basidia have a slightly swollen apex. Sessile ovoidal to drop-shaped basidiospores $(3-4 \times 6-7 \mu \mathrm{m})$ are formed on the apical portion of the basidia. Basidiospores germinate by budding.

The self-fertile strain CBS $10757^{\mathrm{T}}$ is designated the type strain. The type strain has been deposited at the CBS, Utrecht, The Netherlands. This strain was isolated in 2000 from subsurface estuarine water collected in Porto 
Table 2. Physiological and biochemical characteristics of strains of Cystofilobasidium lacus-mascardii sp. nov.

+, Growth; -, no growth; D, delayed growth; w, weak growth. All three strains were positive for assimilation of D-glucose, L-sorbose, Dribose, D-xylose, L-arabinose, D-arabinose, sucrose, maltose, $\alpha, \alpha$ trehalose, cellobiose, salicin, raffinose, melezitose, glycerol, mesoerythritol, D-glucitol, D-mannitol, $m y o$-inositol, glucono- $\delta$-lactone, Dglucuronic acid, succinic acid, ethanol, nitrate, L-lysine and cadaverine. All three strains were also positive for growth with $0.01 \%$ cycloheximide, growth at $25{ }^{\circ} \mathrm{C}$, formation of starch-like compounds, hydrolysis of arbutin and urea and the diazonium blue $\mathrm{B}$ reaction. All three strains were negative for fermentation of D-glucose, assimilation of D-glucosamine, methyl $\alpha$-D-glucoside, inulin, soluble starch, galactitol, L-tartaric acid, D-tartaric acid, $m$-tartaric acid, saccharic acid, mucic acid, protocatechuic acid, methanol, vanillic acid, ferulic acid, veratric acid, $p$-hydroxybenzoic acid, $m$-hydroxybenzoic acid, gallic acid, salicylic acid, gentisic acid, catechol and phenol. All three strains were negative for growth in vitamin-free medium and at $30{ }^{\circ} \mathrm{C}$. All three strains showed delayed assimilation of lactose, weak assimilation of ethylamine and weak and delayed assimilation of DL-lactic acid.

\begin{tabular}{|lccc|}
\hline Characteristic & CRUB & CRUB & CRUB \\
& $\mathbf{1 0 4 6}^{\text {T }}$ & $\mathbf{1 1 7 2}$ & $\mathbf{1 1 7 5}$ \\
\hline Assimilation of: & & & \\
D-Galactose & $\mathrm{D}$ & $\mathrm{D}$ & + \\
L-Rhamnose & $\mathrm{D}$ & + & + \\
Melibiose & - & $\mathrm{wD}$ & $\mathrm{W}$ \\
Ribitol & $\mathrm{W}$ & $\mathrm{W}$ & $\mathrm{WD}$ \\
Xylitol & + & $\mathrm{D}$ & $\mathrm{D}$ \\
D-Gluconic acid & WD & $\mathrm{W}$ & $\mathrm{W}$ \\
Citrate & $\mathrm{W}$ & + & + \\
L-Malic acid & $\mathrm{W}$ & + & + \\
Sodium nitrite & $\mathrm{W}$ & + & + \\
Creatine & + & $\mathrm{W}$ & $\mathrm{W}$ \\
Cadaverine & $\mathrm{W}$ & $\mathrm{W}$ & - \\
D-Glucosamine & - & - & $\mathrm{W}$ \\
Growth with 0.1 \% & + & $\mathrm{wD}$ & $\mathrm{D}$ \\
cycloheximide & & & \\
\hline
\end{tabular}

Brandão, Tagus River, Lisbon, Portugal, by one of us (M. G.).

\section{Phylogenetic placement and phenotypic characteristics}

In this paper, we propose two novel species in the genus Cystofilobasidium, thus enlarging its content to six species (Fig. 3). Presently, Cystofilobasidium accommodates all the pink yeasts of the Cystofilobasidiales, with the exception of Xanthophyllomyces dendrorhous, a distantly related species. The phylogenetic analysis shown in Fig. 3 indicated that Cystofilobasidium lacus-mascardii and Cystofilobasidium macerans are closely related. The LSU rDNA D1/D2 sequences of the two species differ by 8 nucleotide substitutions. The ITS region of Cystofilobasidium lacusmascardii was also studied, and its phylogenetic analysis
Table 3. Relevant physiological traits within the genus Cystofilobasidium

Species: 1, Cystofilobasidium ferigula; 2, Cystofilobasidium bisporidii; 3, Cystofilobasidium capitatum; 4, Cystofilobasidium infirmominiatum; 5, Cystofilobasidium lacus-mascardii sp. nov.; 6, Cystofilobasidium macerans sp. nov. v, Variable response.

\begin{tabular}{|lcccccc|}
\hline Trait & $\mathbf{1}$ & $\mathbf{2}$ & $\mathbf{3}$ & $\mathbf{4}$ & $\mathbf{5}$ & $\mathbf{6}$ \\
\hline Assimilation of: & & & & & & \\
$\quad$ Erythritol & - & - & - & - & + & + \\
Lactose & - & - & + & $\mathrm{V}$ & + & + \\
Melibiose & - & + & - & - & + & $\mathrm{V}$ \\
L-Malic acid & - & + & + & + & + & + \\
L-Tartaric acid & - & - & - & + & - & - \\
Ethylamine & - & + & + & + & + & + \\
Cadaverine & - & + & + & + & + & + \\
Growth at $25{ }^{\circ} \mathrm{C}$ & + & + & - & + & + & + \\
Growth at $30{ }^{\circ} \mathrm{C}$ & + & - & - & - & - & - \\
\hline
\end{tabular}

confirmed a close relationship to Cystofilobasidium macerans (data not shown). Although of limited value because of the low frequency of mating in Cystofilobasidium macerans, mating studies between Cystofilobasidium lacus-mascardii and Cystofilobasidium macerans were always negative, which supports the recognition of two distinct species.

These two species also share several physiological properties and are basically indistinguishable on the basis of patterns of utilization of carbon and nitrogen sources. A noticeable characteristic is the ability to grow with erythritol, a trait that is absent in the remaining species of the genus. A comparison of the salient physiological differences between the species currently assigned to Cystofilobasidium is depicted in Table 3. Most species of Cystofilobasidium show a preference for low temperatures. As shown in Table 3 , the ability to grow at $30{ }^{\circ} \mathrm{C}$ is present only in Cystofilobasidium ferigula, and Cystofilobasidium capitatum is even unable to grow at $25{ }^{\circ} \mathrm{C}$. For Cystofilobasidium macerans, in spite of its ability to grow at $25{ }^{\circ} \mathrm{C}$, we observed that the formation of structures related to the sexual state (mycelium and teliospores) required low temperatures $\left(16{ }^{\circ} \mathrm{C}\right)$.

Cystofilobasidium macerans is based on Cryptococcus macerans, an asexual yeast described by Frederiksen (1956). The specific epithet macerans was chosen to reflect the relevance of the species during retting, which is the process of separating fibre from other plant materials in flax. Frederiksen (1956) found that this species was abundant in the winter months during dew-retting of flax in Denmark. Data from several other studies (Birgisson et al., 2003; Butinar et al., 2007; de García et al., 2007) suggest that Cystofilobasidium macerans is a cold-adapted species, because it has been found in frozen samples (Iceland), glacier ice (Norway) and glacial meltwater (Argentina). The description of Cystofilobasidium macerans is based on the study of heterothallic and self-fertile strains. Sexual 
compatibility in Cystofilobasidium macerans was difficult to investigate because mating reactions seem to occur at a very low rate. In our study, crosses of sexually compatible strains frequently gave negative results. This difficulty in observing mating reactions in Cystofilobasidium macerans probably accounts for our inability to determine the sexuality of several of the strains that were studied (Table 1). Under these circumstances, the availability of self-fertile strains had obvious advantages and, consequently, we propose one of these strains as the type strain of Cystofilobasidium macerans; CBS $10757^{\mathrm{T}}$ was chosen for this purpose because it had a higher frequency of teliospore germination than CBS 6984.

The basidial morphology of Cystofilobasidium lacusmascardii clearly resembles that of Cystofilobasidium macerans and Cystofilobasidium infirmominiatum, but the basidiospores of Cystofilobasidium lacus-mascardii tend to be larger than those of the other two species (basidiospore length is 7-10 $\mu \mathrm{m}$ in Cystofilobasidium lacus-mascardii, 6$7 \mu \mathrm{m}$ in Cystofilobasidium macerans and $5-6 \mu \mathrm{m}$ in Cystofilobasidium infirmominiatum). Both novel species share a peculiar characteristic in that their basidiospores are prone to the production of numerous yeast cells by budding while still being attached to the basidium (Figs 2 and 4). Other interesting characteristics of Cystofilobasidium lacus-mascardii are its ability to synthesize large quantities of carotenoid pigments (Libkind \& van Broock, 2006) and the production of a wide range of extracellular enzymes such as aminopeptidases, proteases, cellulases, pectinases, polygalacturonases, esterases and lipases (Libkind, 2006; Brizzio et al., 2007). The low cell density of Cystofilobasidium lacus-mascardii in water of Lake Mascardi $\left(\sim 2\right.$ cells $\left.1^{-1}\right)$ registered on the two occasions of isolation and the broad extracellular enzyme activity displayed by this species indicate that it may be not an autochthonous member of the surveyed aquatic environment. It is conceivable that the original habitat of Cystofilobasidium lacus-mascardii is the phylloplane, where such an enzyme battery would be most useful.

\section{Additional Cystofilobasidium species from Patagonia}

Species of the Cystofilobasidiales such as Cystofilobasidium capitatum, Cystofilobasidium infirmominiatum and Cystofilobasidium macerans were also isolated from Patagonian aquatic environments along with other terrestrial substrates (woodland soil samples) (Table 1). Isolates of the homothallic species Cystofilobasidium capitatum outnumbered the other yeast species and had a broader distribution, as they were collected from both aquatic and terrestrial substrates. Similarly, in the River Danube, Cystofilobasidium capitatum was the most frequently isolated red yeast species in winter (Sláviková \& Vadkertiová, 1997) and also occurred in various types of forests soils from Slovakia (Sláviková \& Vadkertiová, 2000). These results and the frequent occurrence of
Cystofilobasidium capitatum in Patagonian natural environments can be associated with the ability of this species to grow relatively well at low temperatures such as $5{ }^{\circ} \mathrm{C}$. Another aspect that may reflect an adaptation of Cystofilobasidium capitatum to cold habitats is the reported ability of this species to produce cold-active (psychrophilic) extracellular enzymes (Birgisson et al., 2003; Nakagawa et al., 2004, 2005; Brizzio et al., 2007). Interestingly, only asexual strains (CRUB 1008, 1012, 1014 and 1015) were recovered from soil samples, whereas the sexual strain CRUB 1047 was found in water samples. As shown by the MSP-PCR fingerprinting analysis, all the Cystofilobasidium capitatum strains shared identical DNA banding patterns (Fig. 1).

Two strains of the heterothallic yeast species Cystofilobasidium infirmominiatum (CRUB 1045 and CRUB 1066) were also studied. They showed variable MSP-PCR profiles, somewhat similar to those of the type strain (CBS $323^{\mathrm{T}}$ ) and other reference strains (Fig. 1), and were definitively identified by sequence analysis of the LSU rDNA D1/D2 domain. The identification was also confirmed by the formation of true mycelium and teliospores in crosses of CRUB 1045 with CBS 2204 (mating type A2) or CBS 5015 (mating type A3), but not in crosses with strain CBS $323^{\mathrm{T}}$ (mating type A1); we therefore conclude that strain CRUB 1045 belongs to mating type A1 of Cystofilobasidium infirmominiatum. Strain CRUB 1066 failed to produce the sexual stage and was thus considered anamorphic.

\section{Acknowledgements}

This work was partially funded by the Universidad Nacional del Comahue, Consejo Nacional de Investigaciones Científicas y Tecnológicas, CONICET (project PIP 6536), and Agencia Nacional de Investigaciones Científicas, ANPCyT (projects PICTR2003-00528 and PICT2004-22200). We thank Dr Vincent Robert from the CBS for sending valuable cultures of Cryptococcus macerans and $\mathrm{Dr}$ Michael Weiß (University of Tübingen, Germany) for preparing the Latin diagnoses.

\section{References}

Ahearn, D. G. \& Roth, F. J. (1966). Physiology and ecology of psychrotrophic carotenogenic yeasts. Dev Ind Microbiol 7, 301-309.

Barnett, J. A., Payne, R. W. \& Yarrow, D. (2000). Yeasts. Characteristics and Identification, 3rd edn. Cambridge: Cambridge University Press.

Birgisson, H., Delgado, O., Arroyo, L. G., Hatti-Kaul, R. \& Mattiasson, B. (2003). Cold-adapted yeasts as producers of cold-active polygalacturonases. Extremophiles 7, 185-193.

Brizzio, S., Turchetti, B., de García, V., Libkind, D., Buzzini, P., Gasparetti, C. \& van Broock, M. (2007). Extracellular enzymatic activities (EEA) in basidiomycetous yeasts isolated from glacial and subglacial waters of northwest Patagonia (Argentina). Can J Microbiol 53, 519-525.

Butinar, L., Spencer-Martins, I. \& Gunde-Cimerman, N. (2007). Yeasts in high Arctic glaciers: the discovery of a new habitat for eukaryotic microorganisms. Antonie van Leeuwenhoek 91, 277-289. 
de García, V., Brizzio, S., Libkind, D., Buzzini, P. \& van Broock, M. (2007). Biodiversity of cold-adapted yeasts from glacial meltwater rivers in Patagonia, Argentina. FEMS Microbiol Ecol 59, 331-341.

Díaz, M., Pedrozo, F. \& Baccala, N. (2000). Summer classification of Southern Hemisphere temperate lakes (Patagonia, Argentina). Lakes Reservoirs 5, 213-229.

Edgar, R. C. (2004). MUSCLE: multiple sequence alignment with high accuracy and high throughput. Nucleic Acids Res 32, 1792-1797.

Fell, J. W. \& Statzell-Tallman, A. (1998). Cryptococcus Vuillemin. In The Yeasts, a Taxonomic Study, 4th edn, pp. 693-699. Edited by C. P. Kurtzman \& J. W. Fell. Amsterdam: Elsevier.

Fell, J. W., Roeijmans, H. \& Boekhout, T. (1999). Cystofilobasidiales, a new order of basidiomycetous yeasts. Int J Syst Bacteriol 49, 907-913.

Felsenstein, J. (1985). Confidence limits on phylogenies: an approach using the bootstrap. Evolution 39, 783-791.

Fonseca, A. (1992). Utilization of tartaric acid and related compounds by yeasts: taxonomic implications. Can J Microbiol 38, 1242-1251.

Frederiksen, P. S. (1956). A new Rhodotorula species, Rhodotorula macerans sp. n. isolated from field retted flax straw. Friesia 5, 234-239.

Libkind, D. (2006). Levaduras carotenogénicas de ambientes acuáticos de la Patagonia noroccidental Argentina. Aplicaciones biotecnológicas. $\mathrm{PhD}$ thesis, Universidad Nacional de Tucumán, Argentina (in Spanish).

Libkind, D. \& van Broock, M. R. (2006). Biomass and carotenoid pigment production by Patagonian native yeasts. World J Microbiol Biotechnol 22, 687-692.

Libkind, D., Brizzio, S., Ruffini, A., Gadanho, M., van Broock, M. R. \& Sampaio, J. P. (2003). Molecular characterization of carotenogenic yeasts from aquatic environments in Patagonia, Argentina. Antonie van Leeuwenhoek 84, 313-322.

Libkind, D., Gadanho, M., van Broock, M. R. \& Sampaio, J. P. (2005). Sporidiobolus longiusculus sp. nov. and Sporobolomyces patagonicus sp. nov., novel yeasts of the Sporidiobolales isolated from aquatic environments in Patagonia, Argentina. Int J Syst Evol Microbiol 55, 503-509.

Nakagawa, T., Nagaoka, T., Taniguchi, S., Miyaji, T. \& Tomizuka, N. (2004). Isolation and characterization of psychrophilic yeasts producing cold-adapted pectinolytic enzymes. Lett Appl Microbiol 38, 383-387.
Nakagawa, T., Nagaoka, T., Miyaji, T. \& Tomizuka, N. (2005). A coldactive pectin lyase from the psychrophilic and basidiomycetous yeast Cystofilobasidium capitatum strain PPY-1. Biotechnol Appl Biochem 42, 193-196.

Nei, M. \& Kumar, S. (2000). Molecular Evolution and Phylogenetics. New York: Oxford University Press.

Rayner, R. W. (1970). A Mycological Colour Chart. London: Commonwealth Mycological Institute/British Mycological Society.

Rodrigues de Miranda, L. (1984). Cryptococcus Kützing emend. Phaff et Spencer. In The Yeasts, a Taxonomic Study, 3rd edn, pp. 742-767. Edited by N. J. W. Kreger-van Rij. Amsterdam: Elsevier.

Sampaio, J. P. (1999). Utilization of low molecular weight aromatic compounds by heterobasidiomycetous yeasts: taxonomic implications. Can J Microbiol 45, 491-512.

Sampaio, J. P., Gadanho, M. \& Bauer, R. (2001a). Taxonomic studies on the genus Cystofilobasidium: description of Cystofilobasidium ferigula sp. nov. and clarification of the status of Cystofilobasidium lari-marini. Int J Syst Evol Microbiol 51, 221-229.

Sampaio, J. P., Gadanho, M., Santos, S., Duarte, F. L., Pais, C., Fonseca, A. \& Fell, J. W. (2001b). Polyphasic taxonomy of the basidiomycetous yeast genus Rhodosporidium: Rhodosporidium $\mathrm{kra}$ tochvilovae and related anamorphic species. Int J Syst Evol Microbiol 51, 687-697.

Scorzetti, G., Fell, J. W., Fonseca, A. \& Statzell-Tallman, A. (2002). Systematics of basidiomycetous yeasts: a comparison of large subunit D1/D2 and internal transcribed spacer rDNA regions. FEMS Yeast Res 2, 495-517.

Sláviková, E. \& Vadkertiová, R. (1997). Seasonal occurrence of yeasts and yeast-like organisms in the River Danube. Antonie van Leeuwenhoek 72, 77-80.

Sláviková, E. \& Vadkertiová, R. (2000). The occurrence of yeasts in the forest soils. J Basic Microbiol 40, 207-212.

Tamura, K., Dudley, J., Nei, M. \& Kumar, S. (2007). MEGA4: molecular evolutionary genetics analysis (MEGA) software version 4.0. Mol Biol Evol 24, 1596-1599.

Yarrow, D. (1998). Methods for the isolation, maintenance and identification of yeasts. In The Yeasts, a Taxonomic Study, 4th edn, pp.77-100. Edited by C. P. Kurtzman \& J. W. Fell. Amsterdam: Elsevier. 